Brit. J. prev. soc. Med. (1969). 23, 40-44

\title{
DEVELOPMENT OF ALCOHOL ADDICTION IN YOUNG MEN
}

BY

\author{
CHRISTINE HASSALL*, M.Sc.
}

Late Member of Scientific Staff, Medical Research Council, Unit for Research on the Epidemiology of Psychiatric Illnesses, Edinburgh University Department of Psychiatry, Royal Edinburgh Hospital

Several studies have described the typical stages in the development of alcohol addiction, but these have always been concerned with populations of predominantly middle-aged alcoholics. The aim of this report is to describe the drinking history of a group of young alcoholics aged 30 years and under.

A series of forty young male alcoholics were studied in relation to their drinking history. This work was part of a larger study and the methodology and characteristics of this group will be described in greater detail elsewhere (Hassall, 1968).

\section{Patients AND Methods}

The patients were interviewed at a number of psychiatric hospitals in Scotland and England. The criteria for alcoholism were those of Kessel and Walton (1965):

"Alcoholics are people with a disease that can be defined in medical terms and requires a proper regime of treatment. Alcoholics are addicted to alcohol. Alcohol addicts are unable spontaneously to give up drinking. Though they may go without a drink for a few days, or sometimes for even longer periods, inevitably they revert ... . he (the alcoholic) generally suffers from withdrawal symptomsshort lived (though often serious) physical or mental ill-effects which supervene when drinking is temporarily halted for a few days or even hours".

To be included in the study a patient had to be either a new referral or attending for treatment after a break of at least 6 months since his last spell of treatment.

Every patient was interviewed by the author as soon as possible after admission. Pre-coded schedules were used to record information.

-Now Senior Research Associate, Department of Psychiatry, Queen Blimbeth Hospital, Birmingham.

\section{FINDINGS}

Patients were asked to recall the age at which they had their first drink. The mean age for the group was 15.4 years, but there was a considerable range-from 5 to 21 years. Regular drinking began on average just over 2 years later (16.9 years). The mean of the replies to a question regarding age at onset of excessive drinking was 19.9 years. The Figure shows the development of the drinking habits of the group.

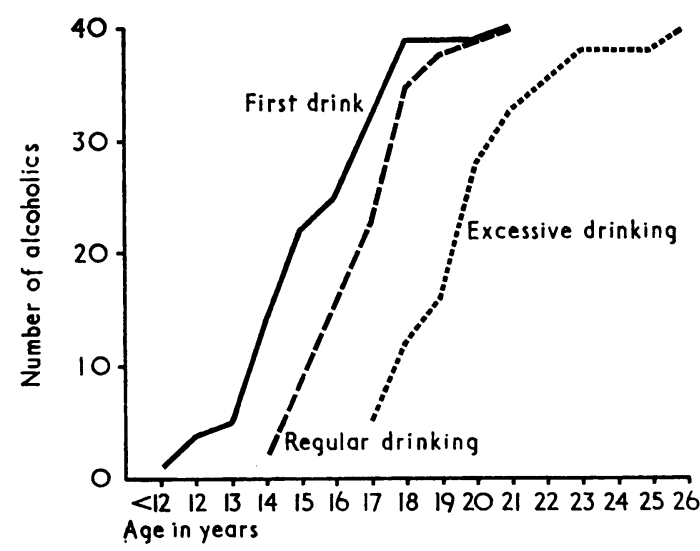

Frouns_-Drinkins patterns of young alcoholics, by age (cumulative frequencies).

All the patients were questioned about events in their drinking history. The questions were based on a list of crucial events considered by Kessel and Walton (1965) to be experienced by most alcoholics and divided into three stages; excessive drinking, alcohol addiction, and chronic alcoholism. Table I sets out these events in the drinking history and the number of patients who had experienced them. 
TABLE I

EVENTS IN DRINKING HISTORY

\begin{tabular}{|c|c|c|c|}
\hline \multirow[b]{2}{*}{ Stage } & \multirow[b]{2}{*}{ Events } & \multicolumn{2}{|c|}{ Alcoholics } \\
\hline & & Number & $\begin{array}{c}\text { Per } \\
\text { cent. }\end{array}$ \\
\hline $\begin{array}{l}\text { A. Excessive } \\
\text { drinking }\end{array}$ & $\begin{array}{l}\text { Drink takes precedence over } \\
\text { other activities } \\
\text { Drinks to get relief from tension } \\
\text { Drinks to perform adequately } \\
\text { socially } \\
\text { Adopts strategies to get drink } \\
\text { Drinks to perform adequately } \\
\text { at work }\end{array}$ & $\begin{array}{r}40 \\
31 \\
28 \\
6 \\
4\end{array}$ & $\begin{array}{l}100 \\
77 \cdot 5 \\
70 \\
15 \\
10\end{array}$ \\
\hline $\begin{array}{l}\text { B. Alcohol } \\
\text { addiction }\end{array}$ & $\begin{array}{l}\text { Amnesias increase in frequency } \\
\text { Drunkenness in the day-time } \\
\text { Unable to stop once started } \\
\text { drinking } \\
\text { Drop in efficiency at work } \\
\text { Suicidal thoughts or impulses } \\
\text { Morning drinking } \\
\text { Drinks every day } \\
\text { Drink expenses interfere with } \\
\text { the housekeeping (or } \\
\text { budget) } \\
\text { Debts due to drinking } \\
\text { Attempts to stop drinking } \\
\text { Loss of a job through drink } \\
\text { Break-up of family through } \\
\text { drink (not necessarily per- } \\
\text { manent) } \\
\text { Suicidal attempts } \\
\text { Wife takes over more respon- } \\
\text { sibilities }\end{array}$ & $\begin{array}{l}40 \\
36 \\
33 \\
32 \\
32 \\
29 \\
28 \\
\\
\\
23 \\
21 \\
21 \\
20 \\
\end{array}$ & $\begin{array}{l}100 \\
90 \\
82 \cdot 5 \\
80 \\
80 \\
72 \cdot 5 \\
70 \\
\\
57 \cdot 5 \\
52 \cdot 5 \\
52 \cdot 5 \\
50 \\
\\
50 \\
45 \\
40\end{array}$ \\
\hline $\begin{array}{l}\text { C. Chronic } \\
\text { alcoholism }\end{array}$ & $\begin{array}{l}\text { Loss of appetite } \\
\text { Neglects meals (spends money } \\
\text { on alcohol) } \\
\text { Drinks cheap wines or } \\
\text { methylated spirits } \\
\text { Tolerance to alcohol } \\
\text { diminishes } \\
\text { Delirium tremens } \\
\text { Attended Alcoholics Anony- } \\
\text { mous }\end{array}$ & $\begin{array}{r}34 \\
31 \\
16 \\
15 \\
14 \\
9\end{array}$ & $\begin{array}{l}85 \\
77 \cdot 5 \\
40 \\
37 \cdot 5 \\
35 \\
22 \cdot 5\end{array}$ \\
\hline
\end{tabular}

(1) In the first stage, that of excessive drinking, all the young alcoholics had given up part of their normal activities in favour of drinking; threequarters of them claimed to drink to relieve tension. Although 28 patients gave "to help mix socially" as one of the reasons for their drinking, nearly as many (23) were drinking alone regularly when interviewed for this study. Only six alcoholics had to adopt strategies to obtain drink and only four drank to perform adequately at work.

(2) In the second stage, that of alcohol addiction, all the patients had experienced amnesias. Drunkenness in the day-time had occurred in all but four of the young people, though many who drank every day managed to confine gross day-time drunkenness to the weekends. Those of the group who were sometimes unable to stop drinking once they had started said that on these occasions they drank until they were too drunk to take more alcohol, or until they ran out of money.

A large number of this group (32) had noticed a drop in efficiency at work. Those in skilled jobs complained of loss of concentration and forgetfulness, and those who were labourers felt weak and lethargic much of the time.

Twenty patients had lost at least one job through drink; this took place in two ways-directly, through being drunk on the job, or indirectly, through missing work because of a hangover or staying on drinking at lunch time instead of returning to work.

Morning drinking was a frequent practice among these young alcoholics (29) and was seen by many of them as a sign of deterioration.

Most patients drank every day unless they were short of money. Just over a quarter of the group appeared to be able to tolerate periods of abstinence, though these periods rarely lasted longer than 5 or 6 days. 23 patients found that the cost of drinking interfered with their budget. Since many of these men were spending about $£ 2$ a day on alcohol it is difficult to see how those who were married could have avoided cutting down the housekeeping money.

Just over half the group (21) claimed that they had attempted to stop drinking in the past. In some cases this meant cutting down the amount or drinking on fewer occasions; rarely did it mean stopping completely. It was universally unsuccessful.

Break-up of the family due to the patient's drinking had occurred in twenty cases though the separations were not always permanent. Eighteen patients had made one or more attempts on their lives and more than three-quarters of the group had contemplated suicide at one time or another.

(3) In the third stage, that of chronic alcoholism physical symptoms became more prominent. Many patients suffered nausea, vomiting, and gastric pain; they would frequently go for days without eating properly because they had lost all desire for food, and even when they thought they should eat they preferred to spend the money on alcohol. Most of the group had experienced morning shakes. These symptoms appeared to be accepted by the patients as a necessary evil. Pins and needles or numbness in the hands and feet had occurred in almost half the patients, but they did not always connect these sensations with alcohol abuse.

Patients who said they had suffered delirium tremens were asked to describe the experience. Probing revealed that three of them had confused delirium tremens with morning shakes, but fourteen alcoholics described auditory and visual hallucinations and feelings of extraordinary fear.

Only one patient had drunk methylated spirits. 
This was while he was in prison where it was the only alcohol available. Just over a third of the alcoholics drank cheap wine. Nine patients used it as their main drink and six as an adjunct to spirits when they were low on funds. None had begun by drinking cheap wine; they had simply graduated to it to get the maximum alcohol content for the minimum money.

Nine of the series had attended Alcoholics Anonymous; these were all alcoholics who had previously received treatment for their addiction in a hospital where attendance at A.A. meetings was part of the regimen, and none of these patients had continued their contact with A.A. after leaving hospital.

Fifteen of the alcoholics had already received treatment for their addiction, some on more than one occasion. Only one of these patients had remained abstinent for more than a fortnight after treatment.

Table II shows the reasons given by these patients for coming for treatment on the occasion of the present enquiry. Twelve young men said they had come of their own volition but closer inspection revealed that most of these had come to escape from intolerable social pressures rather than from a desire to give up drinking for their own benefit. Those alcoholics who came for treatment because they had been charged with some offence (such as drunken driving) are included in the "own volition" group. Those who were "in trouble with the police" came by recommendation from the court or probation officer. The largest group who were "persuaded by a non-relative" included patients who had been encouraged to attend for treatment by general practitioners, social workers, and in two cases, by a girl friend.

TABLE II

REASON FOR SEEKING TREATMENT

\begin{tabular}{l|c|c}
\hline \multicolumn{1}{c|}{ Reason } & \multicolumn{2}{|c}{ Alcoholics } \\
\cline { 2 - 3 } & Number & Per cent. \\
\hline Own volition & 12 & $30 \cdot 0$ \\
Persuaded by non-relative & 15 & $37 \cdot 5$ \\
Persuaded by relative & 4 & $10 \cdot 0$ \\
Persuaded by spouse & 5 & $12 \cdot 5$ \\
In trouble with the police & 4 & $10 \cdot 0$ \\
\hline Total & 40 & 100 \\
\hline
\end{tabular}

Not one patient mentioned concern with the damage alcohol was doing to him physically or mentally as a reason for seeking treatment. The very small number of young men who did appear to have come for their own benefit spoke in terms of social reinstatement and escape from the harassments consequent upon their drinking. Most of the 3 group were apathetic and pessimistic. One man, $\stackrel{\mathbb{Q}}{?}$ voicing the sentiments of many of the series, said $\vec{\Rightarrow}$ "I just don't like life when I'm sober".

The young alcohol addicts were mainly unhopeful about the outcome of treatment. They rarely spoke of wanting to stop drinking, though some did see this as the only solution to their quite considerable difficulties. Perhaps partly because they had all been के abstinent for a few days when seen by the author, $\overrightarrow{0}$ they were nearly all depressed. Not only were they not positively motivated to have treatment, but they were careless in many cases of their future.

All were asked if they had lost any friends through $\stackrel{\bigcirc}{?}$ their drinking (Table III), but a negative answer generally meant that they had never had any friends to lose. Most of those who protested that they had $+\overrightarrow{0}$ gained friends through their drinking had gained only bar acquaintances.

TABle III

CHANGE IN NUMBER OF FRIENDS SINCE EXCESS DRINKINC

\begin{tabular}{l|c|c|}
\hline \multirow{2}{*}{ Number of friends } & \multicolumn{2}{|c|}{ Alcoholics } \\
\cline { 2 - 3 } & Number & Per cent. \\
\hline More & 6 & $15 \cdot 0$ \\
Less & 15 & $37 \cdot 5$ \\
Same & 19 & $47 \cdot 5$ \\
\hline Total & 40 & 100 \\
\hline
\end{tabular}

DISCUSSION

Half this series of young alcoholics had begun $\supset$ their excessive drinking by the age of 20 years. ? The mean time taken for the alcohol addicts to develop from regular to excessive drinking was $\stackrel{?}{?}$ approximately 3 years.

Since no detailed study of young alcoholics has been reported in the literature, comparison will be $ᄋ$ made with the following studies: Glatt (1961): Vallance (1965) who gave figures for male patients 윽 only; and Walton, Ritson, and Kennedy (1966) $>$ whose figures included both male and female patients.

In the early stages of excessive drinking all the young alcoholics had given up at least part of their $N$ outside activities in order to drink; 67 per cent. of $\omega$ male patients in Glatt's study at Warlingham Park had also done this. All but 2 per cent. of the War- $\stackrel{O}{C}$ lingham Park patients drank to help them mix socially but this was only reported by 70 per cent. of the youngpatients. 
In the stage of alcohol addiction the young alcoholics had all suffered from amnesias, most of them for more than a year and many for more than 3 years. Glatt showed that 78 per cent. of his subjects had experienced amnesias and that 61 per cent. suffered frequent amnesias. Walton reported that amnesias had occurred in 65 per cent. of his patients. Most writers are agreed that the onset of amnesias is a crucial point in the alcoholic's drinking history. Kessel and Walton note that "to the physician they (amnesias) are a clear sign that there cannot be a reversion to moderate, controlled drinking ... when the frequency of amnesias increases so that memory blanks become quite regular they occur not as isolated and shocking events but as repeated aspects of his drinking life, another milestone has been reached". The same authors comment that many alcoholics seek treatment at this stage of their addiction since they can no longer hide from themselves the fact that they are being harmed by drink. Older patients may be disturbed by amnesias but the younger addicts in the present study were not. They simply accepted amnesias as a necessary evil following from their drinking; none of them seemed concerned that this might be evidence that they were doing themselves harm by their abuse of alcohol, and in no case were amnesias given as a reason for seeking treatment.

The young men more commonly experienced daytime drunkenness (90 per cent.) than the older patients from Warlingham Park (74 per cent.). This may be a reflection of the young people's casual attitude to work, or of the difference in the class structure of the two groups of patients; 37 per cent. of the young people were in semi-skilled labouring jobs.

Half the young alcoholics had lost at least one job through drinking. The Warlingham Park study shows the same percentage for this experience despite the age difference of the two groups, and the difference in class.

Morning drinking was considered by patients themselves to be a mark of deterioration, not in terms of physical damage but in terms of how little they could do without alcohol. The fact that it is sometimes difficult to obtain alcohol first thing in the morning may have emphasized this need to those who did not or could not save some from the night before. 86 per cent. of Glatt's patients had experienced the need to drink in the mornings, rather more than the 77 per cent. found in the present study.

Forty-five per cent. of the young alcoholics had made one or more suicide attempts; Glatt reports a much lower figure (24 per cent.) for his male patients. It would seem that the risk of repeated and possibly successful suicidal attempts among the young group is high.

Events described by Kessel and Walton as occurring in the stage of chronic alcoholism might be expected to be found more frequently in studies containing older patients, more of whom are likely to have progressed to this stage. Glatt reports that 77 per cent. of his patients neglected food by reason of lack of money and 89 per cent. by reason of lack of appetite. Eighty-seven per cent. of the young alcoholics had neglected food for one or other of these reasons. An area where the young alcoholics did not present so severe a picture was in decrease in tolerance to alcohol-only 37 per cent. of them reported this phenomenon as opposed to 59 per cent. of the Warlingham Park patients.

Delirium tremens had been experienced by 35 per cent. of the young alcoholics; rather less than observed by Vallance in Glasgow ( 50 per cent.) and considerably more than reported by Walton in Edinburgh ( 7 per cent.). This was also considered by the patients to be a sign of deterioration, in fact one of the worst things that could happen to them.

The use of cheap wines has also been considered to be a mark of deterioration, second only to the use of methylated spirits. 40 per cent. of the young addicts drank cheap wines regularly, but Walton found that only 11 per cent. of his series drank cheap wines. The patients themselves did not appear to see the use of cheap wines as a bad sign.

Seeking help from Alcoholics Anonymous is thought by Kessel and Walton to occur most commonly in the stage of chronic alcoholism. The nine young addicts who attended A.A. in hospital all broke this contact once they were discharged. Edwards, Hensman, Hawker and Williamson (1966) has shown that young people are poorly represented in A.A. One of the alcoholics who had attended meetings said that they did not meet the needs of young people. He felt that instead of "dreary" repetitions of the stories of fellow alcoholics, it would be better if A.A. ran a centre where, for at least part of the evening, people could play darts, dominoes, billiards, etc., and drink coffee or soft drinks with fellow alcoholics. This single young man had no interests at all beyond going to the public house and drinking; his main problem if he were to remain abstinent would be how to fill his time; the kind of centre he envisaged would, for him, replace the public house and his former drinking companions. 
Though this young man found A.A. meetings dreary, they quite obviously appeal to a large number of alcoholics and are vital in helping them to maintain sobriety. If this patient had been able to attend the young A.A. group now formed in his home town he might have found the proceedings more attractive.

From the symptoms reported by this group of young alcoholic patients, the disorder they present in spite of their comparative youth is established alcohol addiction. Events which in some patients commonly span some 5 to 10 years had occurred on average in the course of 3 to 5 years in these young patients. This acceleration of events makes early recognition and treatment of alcoholism crucial in young addicts, and underlines the need for awareness that the condition can and does exist in young men in their late 'teens and twenties.

My thanks are due to Prof. G. M. Carstairs, Dr H. Walton, Dr G. Foulds, and Dr N. Kreitman for their support and advice at different stages of this work.
I am also grateful to the many psychiatrists, surgeons, and physicians who allowed me to interview patients under their care.

\section{REFERENCES}

Edwards, G., Hensman, C., Hawker, A., and WilLiAMSON, V. (1966). Lancet, 2, 382 (Who goes to Alcoholics Anonymous?).

GLATT, M. M. (1961). Acta psychiat. scand., 37, 88 त (Drinking habits of English (middle class) alcoholics).

Hassall, C. (1968). Brit. J. Addict. (in press) A Con- क trolled Study of the Characteristics of Young Male $\vec{O}$ Alcoholics.

Kessel, W. I. N., and Walton, H. J. (1965). "Alcoholism". Penguin Books, London.

VAllance, M. (1965). Brit. J. Psychiat., 111, $348 \stackrel{\text { ? }}{?}$ (Alcoholism. A two-year follow-up study of patients i admited to the psychiatric department of a general hospital).

Walton, H. J., Rrtson, E. B., and KenNeDY, R. I. (1966). Brit. med. J., 2, 1171 (Response of alcoholics to clinic treatment). 